\title{
Elements of nurses' professional image in electronic media and their contexts. The opinion of professionally active nurses
}

\author{
Elementy wizerunku zawodowego pieleggniarek w mediach elektronicznych oraz ich konteksty. \\ Opinia pielęgniarek aktywnych zawodowo
}

Anna Sykut ${ }^{1}$, Klaudia Massalska², Beata Dobrowolska ${ }^{2}$

${ }^{1}$ Prywatna Przychodnia Top Medical w Lublinie/Private Medical Care Top Medical in Lublin ${ }^{2}$ Katedra Rozwoju Pielęgniarstwa, Wydział Nauk o Zdrowiu, Uniwersytet Medyczny w Lublinie/ The Department of Development in Nursing, Faculty of Nursing and Health Sciences Medical University of Lublin

CORRESPONDING AUTHOR/AUTOR DO KORESPONDENCJI:

Anna Sykut

Prywatna Przychodnia Top Medical w Lublinie e-mail: aniasykut@wp.pl

STRESZCZENIE

Słowa kluczowe:

ABSTRACT

\section{ELEMENTY WIZERUNKU ZAWODOWEGO PIELEENIAREK W MEDIACH ELEKTRONICZNYCH ORAZ ICH KONTEKSTY. OPINIA PIELEGNAREK AKUYWNYCH ZAWODOWO}

Cel pracy. Celem pracy było określenie elementów wizerunku zawodowego pielęgniarek, które najczęściej pojawiają się w mediach elektronicznych oraz analiza ich wydźwięku.

Materiał i metodyka. W badaniu ankietowym wzięło udział 171 kobiet i 10 mężczyzn, pielęgniarek/pielęgniarzy aktywnych zawodowo. Badania przeprowadzono w 2015 roku, wykorzystując autorski kwestionariusz ankiety.

Wyniki. Wśród najczęstszych elementów określających wizerunek zawodowy pielęgniarek w mediach elektronicznych były strajki/ protesty $-54,1 \%$ ankietowanych oraz wygląd zewnętrzny pielęgniarki - 40,9\%. Wydźwięk tych elementów został określony przez respondentów jako obojętny. Według ankietowanych pielęgniarek, najrzadziej pojawiającymi się elementami wizerunku w mediach elektronicznych były pewność siebie (7,7\%), samodzielność (10,5\%) oraz uczciwość i sumienność (po 13,3\%). Wydźwięk tych elementów został oceniony jako obojętny z wyjątkiem samodzielności - 36,5\% ankietowanych określiło go jako negatywny. Zdaniem badanych, działania na rzecz poprawy wizerunku w mediach elektronicznych powinny podejmować organizacje zawodowe pielęgniarek i położnych oraz same pielęgniarki/pielęgniarze. Najważniejszym zadaniem, które powinny przedsięwziąć organizacje zawodowe w celu poprawy wizerunku zawody były poprawa płac i warunków pracy oraz utożsamianie pielęgniarek ze środowiskiem zawodowym. Wnioski. Najczęściej pojawiającymi się elementami wizerunku zawodowego pielęgniarek w mediach elektronicznych były strajki/ protesty. Najrzadziej pojawiają się w mediach takie cechy pielęgniarek i grupy zawodowej jak pewność siebie, samodzielność oraz uczciwość i sumienność. Istnieje duża potrzeba działań w zakresie zmian w wizerunku zawodowym pielęgniarek funkcjonującym w mediach elektronicznych.

wizerunek zawodowy, media elektroniczne, pielęgniarki

\section{ELEMENTS OF NURSES' PROFESSIONAL IMAGE IN ELECTRONIC MEDIA AND THEIR CONTEXIS.}

\section{THE OPINION OF PROFESSIONALIY ACTIVE NURSES}

Aim. The aim of the research was to determine the elements of a nurses' professional image, which most frequently appear in the media and the analysis of their connotations.

Material and method. A survey was conducted on 171 women and 10 men; professionally active nurses. The study was carried out in 2015 using a questionnaire created by the author .

Results. Among the most common elements influencing the nurses' professional image in electronic media there were strikes/ protests (54.1\%) and the nurses' external appearance (40.9\%). The tone of the above mentioned elements was assessed by the respondents as indifferent. According to the surveyed nurses, the most infrequently appearing professional traits were: confidence (7.7\%), independence (10.5\%), honesty and conscientiousness (13.3\%). The overtone of these elements was evaluated as indifferent except for the 'independence' which was described by $36.5 \%$ of the respondents as negative. According to the respondents, the efforts to improve the image in electronic media should be done by professional organizations of nurses and midwifes and the nurses themselves. The most important task that should be undertaken by professional organizations in order to improve the overall image would be to increase wages and improve nurses' working conditions and their identification with the professional environment.

Conclusions. The most frequently appearing elements of the professional image of nurses in the electronic media were strikes and protests. Rarely such features of nurses and the profession as self-confidence, independence and honesty and conscientiousness were mentioned. Thus there is a great need for acting towards changing the nurses' professional image in the electronic media.

Key words: professional image, electronic media, nurses 


\section{INTRODUCTION}

Despite efforts of professional organizations and the nurses themselves, the image functioning in the society is that of a nurse who performs routine, uncomplicated activities, and who is just a medical assistant; an image that distorts the role of the nurses in contributing to public health all over the world [1].

The electronic media currently became the most popular form of communication. Therefore, they can help nurses to shape an appropriate, positive professional image, in which nurses play and important role in health care, as well as remove the functioning stereotypes and negative opinion on the profession $[1,2]$.

\section{MATERIAL AND METHOD}

The aim of this research is to determine elements of nurses' professional image, which most often appear in the electronic media and the analysis of its connotations.

The research was conducted on 181 professionally active (100\%) nurses. The study was performed in 2015 using the Internet by creating an electronic questionnaire on the following website http://moje-ankiety.pl/. Anonymity and privacy of the respondents were kept at every step of the research. In the introduction of the questionnaire, respondents were given information on the purpose of the research, anonymity and the ability to withdraw from the study at any time. The link to the questionnaire was placed on Facebook, on the fun pages of Polish Nurses Association, Archive P, a journal "Sztuka pielęgnowania" [Art of nursing care], the Polish Nursing and Midwifery Portal and three nursing student groups.

The author made the questionnaire developed thanks to the work of the Student Research Circle at the Faculty of Health Sciences of the Medical University of Lublin (a group of students: Anna Sykut, Klaudia Massalska i Paweł Dzyr under the supervision of Beata Dobrowolska). The questionnaire consists of 30 closed questions in four main areas: (1) questions about opinion on the image of nurses, (2) television, (3) radio, (4) the Internet. Additionally, there are also questions collecting a basic sociodemographic information about respondents.

Statistical analysis was conducted using two tests: the Mann-Whitney U test and the Kruskal-Wallis test and the application of IBM SPSS Statistics version 2.1.

\section{RESULTS}

Out of the 181 respondents, 171 (94.5\%) were women and $10(5.5 \%)$ men. The age of the respondents varied between 22 and 57 years of age; 36 years on average (SD $=10.65$ ).

Higher education degree in nursing studies was mentioned by $52.5 \%$ of respondents $(\mathrm{N}=95), 37.6 \%(\mathrm{~N}=68)$ had a bachelor's degree in nursing, and 9.9\% $(\mathrm{N}=18)$ secondary nursing education. Almost one in five of the respondents (18.8\%) completed post graduate studies, and slightly more than one third of the respondents $(38.1 \%)$ had a specialization. Among the respondents, the average work experience was 14 years $(S D=11.49)$. The respondents were divided into two groups; those who worked for less than 10 years $(50.8 \%)$ and those who worked for more than 10 years $(49.2 \%)$. Majority of respondents worked in in-patient healthcare (79.6\%).

Half of the respondents assessed the position of the nursing profession as average $(49.7 \%)$ and one in four respondents believed that the position was low (25.4\%). Additionally, $13.8 \%$ rated it as very low and only $10 \%$ of the respondents believed that the position was high or very high.

The respondents believed that electronic media had a high $(43.6 \%)$ or a very high $(33.1 \%)$ impact on the nurses' professional image. Respondents were of the opinion that television, the Internet and the radio present the nursing environment in a bad light. The most negative image was portrayed by the television (84\%), the least negative - on the radio (68.5\%)

Among the elements specified in the questionnaire concerning the image of the nursing profession arising from the electronic media, the respondents indicated strikes/protests (54.1\%), elements of appearance (40.9\%), relations with patients $(32.0 \%)$, and relations with team members (19.3\%). The image most rarely appearing in the media, according to the respondents was confidence (7.7\%), independence (10.5\%), conscientiousness (13.3\%) and honesty (13.3\%) (Table 1).

The respondents were also able to add those elements of the nurse's image that did not appear in the questionnaire. Most frequently mentioned were: lack of equality in the therapeutic team, a servile position in relation to the doctor, mistakes, omissions, stereotypes concerning education, referring to nurses using the term "sister", remuneration, item of clothing: cap, smart dress, lack of independence, excess duties, inability to maintain a conversation, unprofessional approach to the patient. The respondents also highlighted the vagueness of the nurses' image in electronic media indicating that a nurse is dependent and only performs doctor's orders. It is also worth noting that electronic media show the dangers resulting from lack of young nurses and the large emigration of educated people.

Statistical analysis revealed that respondents who completed post-graduate studies $(\mathrm{p}=0.015)$ and those working in outpatient units $(\mathrm{p}=0.007)$ were more convinced that the body language is a part of the nurses' image most frequently appearing in the electronic media $(p<0.05)$. For respondents who have not completed post-graduate studies, the most frequently showed image was that concerning strikes/protests $(p<0.05$; $\mathrm{p}=0.007)$. Respondents with more than 10 years' experience $(\mathrm{p}=0.031)$ also pointed to strikes/protests, similarly as those of younger age ( 30 years and less) $(\mathrm{p}=0.015)$ $(\mathrm{p}<0.05)$.

The connotations of individual elements of the media image were estimated in terms of positive, neutral and negative. For the respondents the most favorable connotation appearing in the electronic media was work experience $(30.4 \%)$ and their professionalism (29.3\%). A negative overtone concerned the relations with members of the 
Anna Sykut, Klaudia Massalska, Beata Dobrowolska

Tab. 1. Respondents' opinions on the assessment of the nurses' professional image in electronic media

\begin{tabular}{|c|c|c|c|c|c|c|}
\hline $\begin{array}{l}\text { Elements of the image in electronic } \\
\text { media }\end{array}$ & & 1 & 2 & 3 & 4 & 5 \\
\hline \multirow{2}{*}{ Elements of the external appearance } & $\mathrm{n}$ & 74 & 56 & 7 & 41 & 3 \\
\hline & $\%$ & 40.9 & 30.9 & 3.9 & 22.7 & 1.7 \\
\hline \multirow{2}{*}{ Body language } & $\mathrm{n}$ & 26 & 53 & 41 & 55 & 6 \\
\hline & $\%$ & 14.4 & 29.3 & 22.7 & 30.4 & 3.3 \\
\hline \multirow{2}{*}{ Nurse - patient relations } & $\mathrm{n}$ & 58 & 84 & 13 & 24 & 2 \\
\hline & $\%$ & 32.0 & 46.4 & 7.2 & 13.3 & 1.1 \\
\hline \multirow{2}{*}{$\begin{array}{l}\text { Relations with the members of the } \\
\text { therapeutic team }\end{array}$} & $\mathrm{n}$ & 35 & 72 & 17 & 45 & 12 \\
\hline & $\%$ & 19.3 & 39.8 & 9.4 & 24.9 & 6.6 \\
\hline \multirow{2}{*}{ Professionalism } & $\mathrm{n}$ & 38 & 54 & 21 & 50 & 18 \\
\hline & $\%$ & 21.0 & 29.8 & 11.6 & 27.6 & 9.9 \\
\hline \multirow{2}{*}{ Honesty } & $\mathrm{n}$ & 24 & 54 & 31 & 59 & 13 \\
\hline & $\%$ & 13.3 & 29.8 & 17.1 & 32.6 & 7.2 \\
\hline \multirow{2}{*}{ Diligence } & $\mathrm{n}$ & 32 & 47 & 21 & 69 & 12 \\
\hline & $\%$ & 17.7 & 26.0 & 11.6 & 38.1 & 6.6 \\
\hline \multirow{2}{*}{ Conscientiousness } & $\mathrm{n}$ & 24 & 48 & 30 & 66 & 13 \\
\hline & $\%$ & 13.3 & 26.5 & 16.6 & 36.5 & 7.2 \\
\hline \multirow{2}{*}{ Independence } & $\mathrm{n}$ & 19 & 38 & 24 & 67 & 33 \\
\hline & $\%$ & 10.5 & 21.0 & 13.3 & 37.0 & 18.2 \\
\hline \multirow{2}{*}{ The level of procedures fulfilling } & $\mathrm{n}$ & 28 & 49 & 25 & 62 & 17 \\
\hline & $\%$ & 15.5 & 27.1 & 13.8 & 34.3 & 9.4 \\
\hline \multirow{2}{*}{ Education } & $\mathrm{n}$ & 28 & 50 & 18 & 66 & 19 \\
\hline & $\%$ & 15.5 & 27.6 & 9.9 & 36.5 & 10.5 \\
\hline \multirow{2}{*}{ Experience } & $\mathrm{n}$ & 30 & 48 & 23 & 68 & 12 \\
\hline & $\%$ & 16.6 & 26.5 & 12.7 & 37.6 & 6.6 \\
\hline \multirow{2}{*}{ Confidence } & $\mathrm{n}$ & 14 & 36 & 35 & 77 & 19 \\
\hline & $\%$ & 7.7 & 19.9 & 19.3 & 42.5 & 10.5 \\
\hline \multirow{2}{*}{ Attitude } & $n$ & 29 & 63 & 31 & 48 & 10 \\
\hline & $\%$ & 16.0 & 34.8 & 17.1 & 26.5 & 5.5 \\
\hline \multirow{2}{*}{ Strikes/protests } & $\mathrm{n}$ & 98 & 50 & 18 & 10 & 5 \\
\hline & $\%$ & 54.1 & 27.6 & 9.9 & 5.5 & 2.8 \\
\hline
\end{tabular}

1- definitely yes, 2 - yes, 3 - I have no opinion, 4 - no, 5 - definitely no

therapeutic team (42.0\%) and nurses' professional independence (36.5\%). The respondents had divided opinions as to the image of nurse-patient relationship in the electronic media; for $30.4 \%$ of the respondents it had positive connotation and for 39.8 negative (Table 2).

It turns out that respondents who completed postgraduate studies were more convinced that the relations with the therapeutic team were a part of the professional image which has positive connotations in mass media ( $\mathrm{p}<0.05$; $\mathrm{p}=0.043$ ). For people working in the inpatient wards, the level of nursing/medical procedures is the element which has a positive overtone in the media $(\mathrm{p}<0.05 ; \mathrm{p}=0.039)$. Respondents who have completed undergraduate studies pointed to diligence as having positive connotations with the profession $(\mathrm{p}<0.05 ; 0.015)$.

Less than half of the respondents (48.6\%) believed that subjects responsible for improving the situation should be professional organizations of nurses and midwifes. Slightly fewer (47\%) of the respondents felt that each and every
Tab. 2. Respondents' opinion concerning the overtone of individual elements of the image in the electronic media

\begin{tabular}{|c|c|c|c|c|c|}
\hline $\begin{array}{l}\text { The overtone of the elements portrayed in } \\
\text { the media image }\end{array}$ & & 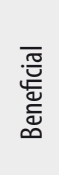 & 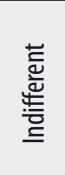 & 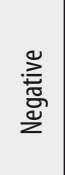 & 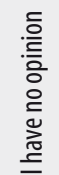 \\
\hline \multirow{2}{*}{ The elements of external appearance } & $\mathrm{n}$ & 51 & 69 & 48 & 138 \\
\hline & $\%$ & 28.2 & 38.1 & 26.5 & 7.2 \\
\hline \multirow{2}{*}{ Body language } & $\mathrm{n}$ & 24 & 83 & 54 & 20 \\
\hline & $\%$ & 13.3 & 45.9 & 29.8 & 11.0 \\
\hline \multirow{2}{*}{ Nurse - patient relations } & $\mathrm{n}$ & 55 & 49 & 72 & 5 \\
\hline & $\%$ & 30.4 & 27.1 & 39.8 & 2.8 \\
\hline \multirow{2}{*}{$\begin{array}{l}\text { Relations with the members of the } \\
\text { therapeutic team }\end{array}$} & $\mathrm{n}$ & 19 & 65 & 76 & 21 \\
\hline & $\%$ & 10.5 & 35.9 & 42.0 & 11.6 \\
\hline \multirow{2}{*}{ Professionalism } & $\mathrm{n}$ & 53 & 51 & 65 & 12 \\
\hline & $\%$ & 29.3 & 28.2 & 35.9 & 6.6 \\
\hline \multirow{2}{*}{ Honesty } & $\mathrm{n}$ & 48 & 75 & 38 & 20 \\
\hline & $\%$ & 26.5 & 41.4 & 21.0 & 11.0 \\
\hline \multirow{2}{*}{ Diligence } & $\mathrm{n}$ & 49 & 58 & 64 & 10 \\
\hline & $\%$ & 27.1 & 32.0 & 35.4 & 5.5 \\
\hline \multirow{2}{*}{ Conscientiousness } & $\mathrm{n}$ & 44 & 65 & 55 & 17 \\
\hline & $\%$ & 24.3 & 35.9 & 30.4 & 9.4 \\
\hline \multirow{2}{*}{ Independence } & $\mathrm{n}$ & 36 & 64 & 66 & 15 \\
\hline & $\%$ & 19.9 & 35.4 & 36.5 & 8.3 \\
\hline \multirow{2}{*}{ The level of procedures fulfilling } & $\mathrm{n}$ & 31 & 63 & 64 & 23 \\
\hline & $\%$ & 17.1 & 34.8 & 35.4 & 12.7 \\
\hline \multirow{2}{*}{ Education } & $\mathrm{n}$ & 50 & 74 & 41 & 16 \\
\hline & $\%$ & 27.6 & 40.9 & 22.7 & 8.8 \\
\hline \multirow{2}{*}{ Experience } & $\mathrm{n}$ & 55 & 75 & 37 & 14 \\
\hline & $\%$ & 30.4 & 41.4 & 20.4 & 7.7 \\
\hline \multirow{2}{*}{ Confidence } & $\mathrm{n}$ & 33 & 76 & 52 & 20 \\
\hline & $\%$ & 18.2 & 42.0 & 28.7 & 11.0 \\
\hline \multirow{2}{*}{ Attitude } & $\mathrm{n}$ & 39 & 66 & 58 & 18 \\
\hline & $\%$ & 21.5 & 36.5 & 32.0 & 9.9 \\
\hline
\end{tabular}

nurse should work on improving the image of the profession. The most important task that organizations should undertake is the improvement in remuneration and the working conditions and the identification of nurses with the professional environment. The smallest importance was assigned to the cooperation with Public Relations companies (Table 3).

Respondents also added to these tasks the ones that were not included in the questionnaire such as creating a positive image of the nurse as a person and a nurse as an employee, participation in workshops aimed at building coherent, fluent and understandable expressions for nonprofessionals, mandatory consultations before production and emission of movies, series, in which the role of the nurse emerges, strengthening of professional solidarity, promotion of nursing studies, promoting proper nurses' attitudes and hiring a more professional and ambitious staff. 
Tab. 3. Assessment of the impact of professional organizations on improving the nurses' professional image in each category

\begin{tabular}{|l|c|c|c|c|c|c|}
\hline $\begin{array}{c}\text { Influence of Professional Organizations } \\
\text { on the improvement of the image }\end{array}$ & & 1 & 2 & 3 & 4 & 5 \\
\hline \multirow{2}{*}{ Greater promotion in electronic media } & $\mathrm{n}$ & 108 & 60 & 7 & 6 & 0 \\
\cline { 2 - 7 } & $\%$ & 59.7 & 33.1 & 3.9 & 3.3 & 0 \\
\hline \multirow{2}{*}{ Cooperation with reporters } & $\mathrm{n}$ & 86 & 59 & 24 & 12 & 0 \\
\cline { 2 - 7 } & $\%$ & 47.5 & 32.6 & 13.3 & 6.6 & 0 \\
\hline \multirow{2}{*}{ Organization of Social Campaigns } & $\mathrm{n}$ & 104 & 60 & 11 & 5 & 1 \\
\cline { 2 - 7 } & $\%$ & 57.5 & 33.1 & 6.1 & 2.8 & 0.6 \\
\hline \multirow{2}{*}{ Cooperation with PR companies } & $\mathrm{n}$ & 72 & 69 & 30 & 10 & 0 \\
\cline { 2 - 7 } & $\%$ & 39.8 & 38.1 & 16.6 & 5.5 & 0 \\
\hline \multirow{2}{*}{$\begin{array}{l}\text { Improvement of pay and the working } \\
\text { conditions }\end{array}$} & $\mathrm{n}$ & 144 & 26 & 6 & 4 & 1 \\
\cline { 2 - 7 } & $\%$ & 79.6 & 14.4 & 3.3 & 2.2 & 0.6 \\
\hline $\begin{array}{l}\text { Associating nurses with the } \\
\text { professional environment }\end{array}$ & $\mathrm{n}$ & 133 & 35 & 12 & 1 & 0 \\
\cline { 2 - 7 } & $\%$ & 73.5 & 19.3 & 6.6 & 0.6 & 0 \\
\hline
\end{tabular}

1 - definitely yes, 2 - yes, 3 - I have no opinion, $4-$ no, 5 - definitely not

\section{DISCUSSION}

Only $10 \%$ of the surveyed nurses believed that their position among other medical professions was high or very high. The poor rating of the profession in the nurses' own opinion was also confirmed by other studies e.g. those conducted by Włodarczyk and Tobolska [3] who exhibited that nurses evaluated their profession lower than doctors and patients.

The respondents also believed that the electronic media present their profession in a bad light and the leading role in this aspect is played by television. The analysis of the collected material showed what kind of image is created by the electronic media. Among the most common elements of the nurses' professional image presented in the media are strikes and protests followed by the elements of nurses' external image. This is also confirmed by other studies [4].

The elements of the image that seldom ever appear in electronic media chosen by the respondents are self-con- fidence, independence, conscientiousness and honesty. These data indicate elements of the image to which we as professionals should pay more attention to and try to expose them in the media.

According to the surveyed nurses, the most favorable connotations in the electronic media were images connected to work experience and the nurses' professionalism. Negative overtone was associated with the relations with other members of the therapeutic team and the nurses' professional independence. This last element is quite often negatively evaluated in the studies concerning nurses' professional image for instance in a literature review carried out by Kojder and Zarzycka [4].

Image plays a huge role in the functioning of any organization. According to Kunecka, in order to build a positive image of the whole health institution, cooperation of employees is necessary, otherwise all actions will be counterproductive to those expected. It is because the employees as well as their individual image have the greatest impact on the reputation of any organization [5]. In the conducted study, $48.6 \%$ of the respondents believed that those responsible for improving the situation in terms of professional image of nurses should be professional association of nurses and midwives, but also every nurse should try to improve the image of his/her own profession (47\% of respondents).

\section{CONCLUSIONS}

The most frequently occurring elements of the nurses' professional image in electronic media were strikes and protests. Seldom ever such features of the nurses and the profession as self-confidence, independence and honesty and conscientiousness were mentioned. What is more, not only was the professional independence of nurses rarely ever visible but the image created by the media was negative in that aspect. Summing up, there is a great need for acting towards changing the nurses' professional image in the electronic media.

\section{Elementy wizerunku zawodowego pielęgniarek w mediach elektronicznych oraz ich konteksty. Opinia pielęgniarek aktywnych zawodowo}

\section{WSTĘP}

Pomimo starań organizacji zawodowych oraz samych pielęgniarek w społeczeństwie wciąż funkcjonuje obraz pielęgniarki wykonującej rutynowe, nieskomplikowane czynności, niesamodzielnej pomocnicy lekarza; obraz, który zafałszowuje rolę pielęgniarki w działaniach na rzecz zdrowia publicznego społeczeństw na całym świecie [1].

Media elektroniczne stały się współcześnie najbardziej nośną i popularną formą przekazu. Dlatego też mogą pomóc pielęgniarkom w kształtowaniu odpowiedniego, pozytywnego wizerunku zawodowego, w którym pielęgniarki odgrywają istotą rolę w ochronie zdrowia, jak również $\mathrm{w}$ usunięciu $\mathrm{z}$ niego funkcjonujących stereotypów oraz negatywnej opinii o zawodzie $[1,2]$. 


\section{MATERIAt I METODYKA}

Celem pracy jest określenie elementów wizerunku zawodowego pielęgniarek, które najczęściej pojawiają się w mediach elektronicznych oraz analiza ich kontekstów.

Badaniami ankietowymi objęto 181 pielęgniarek i pielęgniarzy (100\%) aktywnych zawodowo. Badania przeprowadzono w 2015 roku wykorzystując Internet, tworząc elektroniczną ankietę na stronie internetowej http://mojeankiety.pl/. Zasady anonimowości oraz ochrony prywatności respondentów zostały zachowane na każdym etapie trwania badania. We wstępie do kwestionariusza ankiety respondenci otrzymali informacje dotyczące celu badań, anonimowości oraz możliwości wycofania się z uczestnictwa w badaniach w każdym momencie. Link ankiety umieszczono na Facebook'u, na funpage'ach: Polskiego Towarzystwa Pielęgniarskiego, Archiwum P, Sztuki Pielęgnowania, Portalu Pielęgniarek i Położnych oraz trzech grupach studenckich kierunku pielęgniarstwo.

Autorski kwestionariusz ankiety został opracowany w ramach prac Studenckiego Koła Naukowego przy Katedrze Rozwoju Pielęgniarstwa WNoZ UM w Lublinie przez grupę studentów: Anna Sykut, Klaudia Massalska i Paweł Dzyr pod kierunkiem Beaty Dobrowolskiej. Autorski kwestionariusz ankiety jest narzędziem, które składa się z 30 pytań zamkniętych w czterech głównych blokach tematycznych: (1) pytania dotyczące opinii na temat wizerunku pielęgniarki, (2) telewizja, (3) radio, (4) Internet. Znajdują się w nim również pytania gromadzące podstawowe informacje socjodemograficzne dotyczące respondentów.

W analizie statystycznej zgromadzonego materiału posłużono się dwoma testami: Manna-Whitney'a oraz Kruskala-Wallisa używając programu IBM SPSS Statistics wersja 2.1.

\section{WYNIKI BADAŃ}

$\mathrm{Na} 181$ badanych 171 (94,5\%) stanowiły kobiety, a 10 (5,5\%) mężczyźni. Wiek badanej grupy mieścił się w przedziale od 22 lat do 57 roku życia; średni wiek badanych wyniósł 36 lat $(\mathrm{SD}=10,65) .52,5 \%$ badanych $(\mathrm{N}=95)$ miało wykształcenie wyższe magisterskie z zakresu pielęgniarstwa, 37,6\% $(\mathrm{N}=68)$ licencjat pielęgniarstwa, 9,9\% $(\mathrm{N}=18)$ średnie wykształcenie pielęgniarskie. Prawie co piąty badany $(18,8 \%)$ ukończył studia podyplomowe, a nieco ponad jedna trzecia badanych $(38,1 \%)$ miała specjalizację. W grupie respondentów średni staż pracy wyniósł 14 lat $(\mathrm{SD}=11,49)$. Ankietowanych podzielono na dwie grupy: osoby ze stażem pracy do 10 lat $(50,8 \%)$ oraz ze stażem pracy powyżej 10 lat (49,2\%). Większość badanych pracowała w lecznictwie zamkniętym $(79,6 \%)$.

Połowa badanych oceniła pozycję zawodu pielęgniarki/ pielęgniarza jako średnią $(49,7 \%)$. Co czwarty badany uważał, że ta pozycja jest niska $(25,4 \%)$. Ponadto $13,8 \%$ oceniło ją jako bardzo niską. Niecałe $10 \%$ badanych uważało, że pozycja ich zawodu wśród zawodów medycznych jest wysoka lub bardzo wysoka.

Respondenci uważali, że media elektroniczne mają wysoki $(43,6 \%)$ lub bardzo wysoki $(33,1 \%)$ wpływ na wizerunek ich zawodu. Badani byli zdania, że zarówno telewizja, Internet jak i radio przedstawiają środowisko pielęgniarskie w złym świetle. Najgorszy przekaz wysyła telewizja (84\%), najmniej negatywny - radio $(68,5 \%)$.

Spośród określonych w kwestionariuszu elementów wizerunku zawodu pielęgniarki pojawiających się obecnie w mediach elektronicznych respondenci wskazali strajki/protesty (54,1\%), elementy wyglądu zewnętrznego $(40,9 \%)$, relacje $\mathrm{z}$ pacjentem $(32,0 \%)$, relacje $\mathrm{z}$ członkami zespołu terapeutycznego (19,3\%). Elementami wizerunku najrzadziej pojawiającymi się w mediach elektronicznych według respondentów były: pewność siebie $(7,7 \%)$, samodzielność $(10,5 \%)$, sumienność $(13,3 \%)$ oraz uczciwość $(13,3 \%)$ pielęgniarek (Tab. 1$)$.

Tab. 1. Opinia ankietowanych na temat oceny występowania elementów wizerunku pielęgniarki w mediach elektronicznych

\begin{tabular}{|c|c|c|c|c|c|c|}
\hline Elementy wizerunku w mediach & & 1 & 2 & 3 & 4 & 5 \\
\hline \multirow{2}{*}{ Elementy wyglądu zewnętrznego } & $n$ & 74 & 56 & 7 & 41 & 3 \\
\hline & $\%$ & 40.9 & 30.9 & 3.9 & 22.7 & 1.7 \\
\hline \multirow{2}{*}{ Mowa ciała } & $\mathrm{n}$ & 26 & 53 & 41 & 55 & 6 \\
\hline & $\%$ & 14.4 & 29.3 & 22.7 & 30.4 & 3.3 \\
\hline \multirow{2}{*}{ Relacje z pacjentem } & $\mathrm{n}$ & 58 & 84 & 13 & 24 & 2 \\
\hline & $\%$ & 32.0 & 46.4 & 7.2 & 13.3 & 1.1 \\
\hline \multirow{2}{*}{$\begin{array}{l}\text { Relacje z członkami zespołu } \\
\text { terapeutycznego }\end{array}$} & $\mathrm{n}$ & 35 & 72 & 17 & 45 & 12 \\
\hline & $\%$ & 19.3 & 39.8 & 9.4 & 24.9 & 6.6 \\
\hline \multirow{2}{*}{ Profesjonalizm } & $\mathrm{n}$ & 38 & 54 & 21 & 50 & 18 \\
\hline & $\%$ & 21.0 & 29.8 & 11.6 & 27.6 & 9.9 \\
\hline \multirow{2}{*}{ Uczciwość } & $\mathrm{n}$ & 24 & 54 & 31 & 59 & 13 \\
\hline & $\%$ & 13.3 & 29.8 & 17.1 & 32.6 & 7.2 \\
\hline \multirow{2}{*}{ Pracowitość } & $\mathrm{n}$ & 32 & 47 & 21 & 69 & 12 \\
\hline & $\%$ & 17.7 & 26.0 & 11.6 & 38.1 & 6.6 \\
\hline \multirow{2}{*}{ Sumienność } & $\mathrm{n}$ & 24 & 48 & 30 & 66 & 13 \\
\hline & $\%$ & 13.3 & 26.5 & 16.6 & 36.5 & 7.2 \\
\hline \multirow{2}{*}{ Samodzielność } & $\mathrm{n}$ & 19 & 38 & 24 & 67 & 33 \\
\hline & $\%$ & 10.5 & 21.0 & 13.3 & 37.0 & 18.2 \\
\hline \multirow{2}{*}{ Poziom realizacji procedur } & $\mathrm{n}$ & 28 & 49 & 25 & 62 & 17 \\
\hline & $\%$ & 15.5 & 27.1 & 13.8 & 34.3 & 9.4 \\
\hline \multirow{2}{*}{ Wykształcenie zawodowe } & $\mathrm{n}$ & 28 & 50 & 18 & 66 & 19 \\
\hline & $\%$ & 15.5 & 27.6 & 9.9 & 36.5 & 10.5 \\
\hline \multirow{2}{*}{ Doświadczenie zawodowe } & $\mathrm{n}$ & 30 & 48 & 23 & 68 & 12 \\
\hline & $\%$ & 16.6 & 26.5 & 12.7 & 37.6 & 6.6 \\
\hline \multirow{2}{*}{ Pewność siebie } & $\mathrm{n}$ & 14 & 36 & 35 & 77 & 19 \\
\hline & $\%$ & 7.7 & 19.9 & 19.3 & 42.5 & 10.5 \\
\hline \multirow{2}{*}{ Postawa } & $\mathrm{n}$ & 29 & 63 & 31 & 48 & 10 \\
\hline & $\%$ & 16.0 & 34.8 & 17.1 & 26.5 & 5.5 \\
\hline \multirow{2}{*}{ Strajki/protesty } & $\mathrm{n}$ & 98 & 50 & 18 & 10 & 5 \\
\hline & $\%$ & 54.1 & 27.6 & 9.9 & 5.5 & 2.8 \\
\hline
\end{tabular}

1- zdecydowanie tak, 2 - raczej tak, 3 - nie mam zdania, 4 - raczej nie, 5 - zdecydowanie nie

Respondenci mieli również możliwość dodania tych elementów obrazu zawodu pielęgniarki w mediach, które nie pojawiły się w kwestionariuszu. Najczęściej wymieniano: brak równości w zespole terapeutycznym, pozycja 
służalcza w relacjach lekarz-pielęgniarka, błędy, zaniedbania popełnione przez pielęgniarkę, stereotyp co do wykształcenia, określenie pielęgniarki mianem „siostry”, wynagrodzenie, element stroju: czepek, bardzo duża estetyka ubioru, brak samodzielności, nadmiar obowiązków, nieumiejętność prowadzenia konwersacji, nieprofesjonalne podejście do pacjenta. Ankietowani podkreślili ponadto nijakość wizerunku pielęgniarki w mediach elektronicznych, wskazując, że najczęściej pielęgniarka to osoba niesamodzielna, wykonująca tylko polecenia lekarza. Zauważono także, że media elektroniczne pokazują zagrożenia spowodowane brakiem młodych pielęgniarek oraz bardzo dużą emigrację wykształconych osób.

Analiza statystyczna wykazała, że badani, którzy ukończyli studia podyplomowe $(\mathrm{p}=0,015)$ oraz ci pracujący w lecznictwie otwartym $(\mathrm{p}=0,007)$ byli bardziej przekonani do tego, że mowa ciała pielęgniarki jest elementem wizerunku najczęściej pojawiającym się w mediach elektronicznych $(\mathrm{p}<0,05)$. Dla respondentów, którzy nie ukończyli studiów podyplomowych elementem tym były strajki/protesty $(\mathrm{p}<0,05 ; \mathrm{p}=0,007)$. Ankietowani ze stażem pracy większym niż 10 lat $(\mathrm{p}=0,031)$ również wskazali strajki/protesty, podobnie jak osoby w młodszym wieku (30 lat i mniej) $(\mathrm{p}<0,05 ; \mathrm{p}=0,015)$.

Konteksty poszczególnych elementów wizerunku w mediach oszacowane zostały w kategoriach korzystny, obojętny i negatywny. Dla ankietowanych najkorzystniejsze znaczenie pojawiające się $\mathrm{w}$ mediach elektronicznych miały doświadczenie zawodowe pielęgniarek $(30,4 \%)$ oraz ich profesjonalizm (29,3\%). Negatywne znaczenie miały relacje z członkami zespołu terapeutycznego (42,0\%) oraz samodzielność zawodowa pielęgniarek (36,5\%). Badani podzielili się w opinii co do obrazu relacji pielęgniarki $\mathrm{z}$ pacjentem $\mathrm{w}$ mediach elektronicznych, dla $30,4 \%$ ma on kontekst pozytywny, zaś dla 39,8 kontekst negatywny (Tab. 2).

Okazuje się, że osoby, które ukończyły studia podyplomowe były bardziej przekonane do tego, że relacje $\mathrm{z}$ zespołem terapeutycznym to element wizerunku, który ma korzystną ekspozycję w mediach elektronicznych $(p<0,05 ; p=0,043)$. Dla osób pracujących w lecznictwie zamkniętym poziom realizacji procedur pielęgniarskich/ medycznych to właśnie ten element, który ma korzystną prezentację w mediach $(\mathrm{p}<0,05 ; \mathrm{p}=0,039)$. Badani, którzy ukończyli studia licencjackie wskazali na pracowitość jako oczekiwany aspekt elementu zawodowego pielęgniarki $(\mathrm{p}<0,05 ; \mathrm{p}=0,015)$.

Niespełna połowa respondentów $(48,6 \%)$ uważała, że podmiotami odpowiedzialnymi za poprawę sytuacji powinny być organizacje zawodowe pielęgniarek i położnych. Niewiele mniej (47\%) badanych uważało, że każda pielęgniarka/pielęgniarz powinni poprawiać wizerunek swojego zawodu. Najważniejszym zadaniem, które powinny przedsięwziąć organizacje zawodowe w celu poprawy wizerunku zawodu były poprawa płac i warunków pracy oraz utożsamianie pielęgniarek ze środowiskiem zawodowym. Najmniejsze znaczenie przypisano współpracy z firmami PR (Tab. 3).
Tab. 2. Opinia badanych na temat postrzeganego kontekstu elementów wizerunku w mediach elektronicznych

\begin{tabular}{|c|c|c|c|c|c|}
\hline $\begin{array}{l}\text { Wydźwięk elementów wizerunku } \\
\text { w mediach }\end{array}$ & & 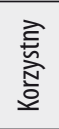 & 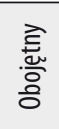 & 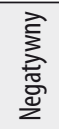 & 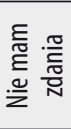 \\
\hline \multirow{2}{*}{ Elementy wyglądu zewnętrznego } & $\mathrm{N}$ & 51 & 69 & 48 & 138 \\
\hline & $\%$ & 28.2 & 38.1 & 26.5 & 7.2 \\
\hline \multirow{2}{*}{ Mowa ciała } & $\mathrm{N}$ & 24 & 83 & 54 & 20 \\
\hline & $\%$ & 13.3 & 45.9 & 29.8 & 11.0 \\
\hline \multirow{2}{*}{ Relacje z pacjentem } & $\mathrm{N}$ & 55 & 49 & 72 & 5 \\
\hline & $\%$ & 30.4 & 27.1 & 39.8 & 2.8 \\
\hline \multirow{2}{*}{$\begin{array}{l}\text { Relacje z członkami zespołu } \\
\text { terapeutycznego }\end{array}$} & $\mathrm{N}$ & 19 & 65 & 76 & 21 \\
\hline & $\%$ & 10.5 & 35.9 & 42.0 & 11.6 \\
\hline \multirow{2}{*}{ Profesjonalizm } & $\mathrm{N}$ & 53 & 51 & 65 & 12 \\
\hline & $\%$ & 29.3 & 28.2 & 35.9 & 6.6 \\
\hline \multirow{2}{*}{ Uczciwość } & $\mathrm{N}$ & 48 & 75 & 38 & 20 \\
\hline & $\%$ & 26.5 & 41.4 & 21.0 & 11.0 \\
\hline \multirow{2}{*}{ Pracowitość } & $\mathrm{N}$ & 49 & 58 & 64 & 10 \\
\hline & $\%$ & 27.1 & 32.0 & 35.4 & 5.5 \\
\hline \multirow{2}{*}{ Sumienność } & $\mathrm{N}$ & 44 & 65 & 55 & 17 \\
\hline & $\%$ & 24.3 & 35.9 & 30.4 & 9.4 \\
\hline \multirow{2}{*}{ Samodzielność } & $\mathrm{N}$ & 36 & 64 & 66 & 15 \\
\hline & $\%$ & 19.9 & 35.4 & 36.5 & 8.3 \\
\hline \multirow{2}{*}{ Poziom realizacji procedur } & $\mathrm{N}$ & 31 & 63 & 64 & 23 \\
\hline & $\%$ & 17.1 & 34.8 & 35.4 & 12.7 \\
\hline \multirow{2}{*}{ Wykształcenie zawodowe } & $\mathrm{N}$ & 50 & 74 & 41 & 16 \\
\hline & $\%$ & 27.6 & 40.9 & 22.7 & 8.8 \\
\hline \multirow{2}{*}{ Doświadczenie zawodowe } & $\mathrm{N}$ & 55 & 75 & 37 & 14 \\
\hline & $\%$ & 30.4 & 41.4 & 20.4 & 7.7 \\
\hline \multirow{2}{*}{ Pewność siebie } & $\mathrm{N}$ & 33 & 76 & 52 & 20 \\
\hline & $\%$ & 18.2 & 42.0 & 28.7 & 11.0 \\
\hline \multirow{2}{*}{ Postawa } & $\mathrm{N}$ & 39 & 66 & 58 & 18 \\
\hline & $\%$ & 21.5 & 36.5 & 32.0 & 9.9 \\
\hline
\end{tabular}

Tab. 3. Ocena wpływu organizacji zawodowych na poprawę wizerunku w poszczególnych kategoriach

\begin{tabular}{|l|c|c|c|c|c|c|}
\hline $\begin{array}{c}\text { Wpływ Organizacji Zawodowych na } \\
\text { poprawę wizerunku }\end{array}$ & & 1 & 2 & 3 & 4 & 5 \\
\hline \multirow{2}{*}{$\begin{array}{l}\text { Większa promocja w mediach } \\
\text { elektronicznych }\end{array}$} & $\mathrm{n}$ & 108 & 60 & 7 & 6 & 0 \\
\cline { 2 - 7 } & $\%$ & 59.7 & 33.1 & 3.9 & 3.3 & 0 \\
\hline \multirow{2}{*}{ Współpraca z dziennikarzami } & $\mathrm{N}$ & 86 & 59 & 24 & 12 & 0 \\
\cline { 2 - 7 } & $\%$ & 47.5 & 32.6 & 13.3 & 6.6 & 0 \\
\hline \multirow{3}{*}{ Organizacja kampanii społecznych } & $\mathrm{n}$ & 104 & 60 & 11 & 5 & 1 \\
\cline { 2 - 7 } & $\%$ & 57.5 & 33.1 & 6.1 & 2.8 & 0.6 \\
\hline \multirow{3}{*}{ Współpraca z firmami PR } & $\mathrm{n}$ & 72 & 69 & 30 & 10 & 0 \\
\cline { 2 - 7 } & $\%$ & 39.8 & 38.1 & 16.6 & 5.5 & 0 \\
\hline \multirow{3}{*}{ Poprawa płac i warunków pracy } & $\mathrm{n}$ & 144 & 26 & 6 & 4 & 1 \\
\cline { 2 - 7 } & $\%$ & 79.6 & 14.4 & 3.3 & 2.2 & 0.6 \\
\hline Utożsamianie pielęgniarek ze & $\mathrm{n}$ & 133 & 35 & 12 & 1 & 0 \\
\cline { 2 - 7 } & $\%$ & 73.5 & 19.3 & 6.6 & 0.6 & 0 \\
\hline środowiskiem zawodowym & $\%$ &
\end{tabular}

1 - Zdecydowanie tak, 2 - raczej tak, 3 - nie mam zdania, 4 - raczej nie, 5 - zdecydowanie nie 
Respondenci dodali również do tych zadań takie, które nie pojawiły się w kwestionariuszu, a mają według nich znaczenie: kreowanie pozytywnego obrazu osoby pielęgniarki i pracownika pielęgniarki, udział w warsztatach pomagających w budowaniu spójnych, płynnych i zrozumiałych dla nieprofesjonalistów wypowiedzi, obowiązkowe konsultacje przed produkcją i emisją filmów, seriali, w których pojawiają się role pielęgniarskie, programów poświęconych pielęgniarkom, wzmacnianie solidarności zawodowej, promocję studiów pielęgniarskich, promowanie odpowiedniej postawy pielęgniarki, zatrudnianie w organizacji bardziej profesjonalnej i ambitnej kadry.

\section{DYSKUSJA}

Zaledwie $10 \%$ badanych pielęgniarek/pielęgniarzy uważało, że pozycja ich zawodu wśród zawodów medycznych jest wysoka lub bardzo wysoka. Niską ocenę pozycji zawodu w ich własnej ocenie potwierdzają także inne doniesienia. Włodarczyk i Tobolska [3] wykazują w swoich badaniach, że pielęgniarki niżej niż lekarze i pacjenci oceniali pozycję swojego zawodu.

Ankietowani w badaniach własnych twierdzą dodatkowo, że media elektroniczne przedstawiają ich profesję w złym świetle, i wiodącą rolę odgrywa w tym względzie telewizja. Analiza zgromadzonego materiału pokazała jaki obraz zawodu pielęgniarki kreują media elektroniczne. Wśród najczęstszych elementów wizerunku zawodowego tej grupy profesjonalistów w mediach, zdaniem badanych pielęgniarek, obecne są strajki i protesty, poza tym elementy wyglądu zewnętrznego pielęgniarki. Potwierdzają ten fakt także inne badania [4].

Elementami wizerunku najrzadziej pojawiającymi się w mediach elektronicznych według respondentów były: pewność siebie pielęgniarek, samodzielność, sumienność oraz uczciwość. Dane te wskazują na te elementy wizerunku, na które powinniśmy jako grupa zawodowa zwracać większą uwagę i starać się eksponować je w mediach.

Według ankietowanych pielęgniarek najkorzystniejszy wydźwięk miały pojawiające się w mediach elektronicznych obrazy dotyczące doświadczenia zawodowego pielęgniarek oraz ich profesjonalizm. Negatywny kontekst miały natomiast relacje z członkami zespołu terapeutycznego oraz samodzielność zawodowa pielęgniarek. Ten ostatni element jest dosyć często niekorzystnie oceniany w badaniach dotyczących wizerunku zawodowego pielęgniarek. Pokazuje to przegląd piśmiennictwa dokonany przez Kojder i Zarzycką [4].

Wizerunek odrywa ogromną rolę w funkcjonowaniu każdej organizacji. Zdaniem Kuneckiej, do zbudowania pozytywnego obrazu całej instytucji zdrowotnej niezbędni są pracownicy, w przeciwnym razie wszystkie działania będą odwrotne od oczekiwanych, ponieważ największy wpływ na reputację danej organizacji mają osoby w niej zatrudnione, jak również wizerunek każdej z nich indywidualnie [5]. W badaniach własnych, 48,6\% ankietowanych uważała, że podmiotami odpowiedzialnymi za poprawę sytuacji w kwestii wizerunku zawodowego pielęgniarek powinny być organizacje zawodowe pielęgniarek i położ- nych, ale także każda pielęgniarka/pielęgniarz powinna starać się poprawiać wizerunek swojego zawodu - 47\% badanych.

\section{WNIOSKI}

Najczęściej pojawiającymi się elementami wizerunku zawodowego pielęgniarek $\mathrm{w}$ mediach elektronicznych były strajki/protesty. Najrzadziej pojawiają się w mediach takie cechy pielęgniarek i grupy zawodowej jak pewność siebie, samodzielność oraz uczciwość i sumienność. Samodzielność zawodowa pielęgniarek nie dość, że pojawia się rzadko, to wydźwięk kreowanego przez media obrazu jest negatywny. Istnieje duża potrzeba działań w zakresie zmian $\mathrm{w}$ funkcjonującym w mediach elektronicznych wizerunku zawodowym pielęgniarek.

\section{PIŚMIENNICTWO/REFERENCES}

1. McAllister M, Downer T, Hanson J, Oprescu F. Transformers: Changing the face of nursing and midwifery in the media. Nurse Education in Practice. 2014; 14(2): 148153.

2. Heilemann M. Media images and screen representations of nurses. Nursing Outlook. 2012; 60: 1-3.

3. Włodarczyk D, Tobolska B. Wizerunek zawodu pielęgniarki z perspektywy lekarzy, pacjentów i pielęgniarek. Medycyna Pracy. 2011; 62(3): 269-279.

4. Kojder E, Zarzycka D. Wizerunek zawodowy pielęgniarki i jego determinanty. Pielęgniarstwo XXI wieku. 2014; 2(47): 47-52.

5. Kunecka D. Jak cię widzą tak cię piszą. Wizerunek zawodowy. Magazyn Pielęgniarki i Położnej. 2011; 9: 4.

Praca przyjęta do druku/Manuscript received: 09.11.2015

Praca zaakceptowana do druku/Manuscript accepted: 12.01.2016

Tłumaczenie/Translation: Anna Zagaja 